\title{
Study on food-feed competitive efficiency of Moringa fodder in the active Brahmaputra-Jamuna Floodplain Agro-Ecological Zone of Bangladesh
}

\author{
Bashar MK ${ }^{1 *}$, KS Huque ${ }^{1}$, NR Sarker ${ }^{2}$, N Sultana ${ }^{1}$ and S Ahmed ${ }^{3}$
}

${ }^{\mathbf{1} A n i m a l}$ Production Research Division, Bangladesh Livestock Research Institute, Savar, Dhaka-1341, Bangladesh; ${ }^{2}$ Project Director, Fodder Research and Development Project, Bangladesh Livestock Research Institute, Savar, Dhaka-1341, Bangladesh; ${ }^{3}$ Ph.D. Fellow, Fodder Research and Development Project, Bangladesh Livestock Research Institute, Savar, Dhaka-1341, Bangladesh

\begin{abstract}
The research work was carried out to evaluate the food-feed competitive efficiency of Moringa fodder in the Active Brahmaputra-Jamuna Floodplain Agro-Ecological Zone (ABJF-AEZ) of Bangladesh. For determining the competitive land use efficiency of Mornga feed $\left(\mathrm{M}_{\mathrm{f}}\right)$ production, the Moringa fodder was cultivated in Gaibandha district at ABJF-AEZ with four replications. The annual dry matter (DM) yield of Moringa at on-farm condition was the height $(26.67$ ton/ha) and it was varied significantly $(P<0.05)$ with on-station condition. Comparing the Moringa fodder with available cash crop, the cost of production of Moringa was higher than that of other two cropping system like Boro-fellow-Jute (BFJ) and BoroFellow-Matikalai (BFM) but the gross return of Moringa cultivation was Tk.186.3 thousand, it was about five times higher income than existing cash crop. For determining the impacts of $M_{f}$ on milk production and their quality, twelve local cows of third or fourth parity after 1 to 2 weeks of calving in Gaibandha Sadar Upazila were selected and divided into three dietary groups having four animals in each considering their live weight and ante-diet daily milk yield. During 50 days feeding period all experimental cows were fed freshly threshed rice straw and keeping randomly a group under on farm practice that received supplementation of conventionally mixed concentrates (CMC), the other two groups of cows were either received a commercial cattle feed available at the market or $M_{f}$ replacing conventional concentrate supplements. $M_{\mathrm{f}}$ produced significant amount of milk $(1.64 \mathrm{~kg} / \mathrm{day})$ and meat $(441.3 \mathrm{~g} /$ day $)$ followed by commercial cattle feed $(1.1 \mathrm{~kg} /$ day and $128.2 \mathrm{~g} /$ day $)$ and CMC $(0.73 \mathrm{~kg} / \mathrm{day}$ and $48.4 \mathrm{~g} /$ day), respectively. It was also indicated that $M_{f}$ is better than market feed for the increase of milk yield and live weight gain. So, $M_{f}$ is an unbeatable animal feed to increase the productivities of cows.
\end{abstract}

Key words: moringa fodder, yield, benefit to cost, milk yield and quality

Bangladesh Animal Husbandry Association. All rights reserved.

Bang. J. Anim. Sci. 2019. 48 (1):36-41

\section{Introduction}

Production of quality feeds and fodder balancing their macro and micro nutrients may support dairy production cost effectively without any threats to human health. Adoptions of their value addition technologies are important for achieving economically sustainable dairy production system in Bangladesh. Considering $M_{f}$ is one of the best options for Bangladesh that may manufacture feed of Moringa (Moringa oleifera) plant twigs and branches and produce safe food for animal origin smartly (Sultana et al., 2012). Agronomical options for on station production of Moringa fodder are generated out of the research works completed in the most recent year (Huque et al., 2017). It also used as a animal feed that may replace conventionally mixed concentrates containing 16.0 to $18.0 \%$ crude protein (CP) for ruminant animals including dairy cattle, and it found to be better than any other feeds and fodder available in the country in terms of efficiency of biomass and animal production, reduction of enteric methane emission and benefit to cost (Huque et al., 2017). All these options need to be tested on farm condition. Growing Moringa fodder in cultivable land is a new approach and farmers will not take any risk for that. Moreover, Moringa feed market also need to be integrated with on farm production system. This requires demonstration of production, value additions and benefits to farmers. All these activities required to be supported by entrepreneur farmers and marketing agent for developing sustainable system of production $\mathrm{M}_{\mathrm{f}}$ and supplying it to users. Backward integration of Moringa producers tackling food-feed competitions for land with its

*Corresponding author: mkbashar@blri.gov.bd 
manufacturing process and creating farmers ' awareness on its feeding benefits help livestock feed industry grow further. Keeping the above factors in view, the present research work was undertaken to determine competitive land use efficiency of $M_{f}$ production on farm compared to existing crops and to demonstrate feeding impacts on farm of dairy cows.

\section{Materials and Methods Location and agro-climate of the experimental site \\ The agronomical trial was conducted Gaibanda Sadar at Gaibanda district in the ABJF-AEZ of Bangladesh during October, 2016 to December, 2017. The station was located at $25^{\circ} 02^{\prime}$ and $25^{\circ} 39^{\prime} \mathrm{N}$ latitudes and in between $89^{\circ} 11^{\prime}$ and $89^{\circ} 46^{\prime} \mathrm{E}$ longitudes of $4 \mathrm{~m}$ above the sea level. The research area is occupied by sandy and silty alluvium, rich in weather able minerals with slightly alkaline in reaction $(\mathrm{pH}$ 5.7-8.2) containing low organic matter $(1.5 \%)$. During the experimental period temperature ranged from $21^{\circ}$ to $35^{\circ} \mathrm{C}$ and humidity ranged from 50 to $75 \%$.}

\section{Preparation of experimental plots}

During the month of October, 2016 the seed of native black were propagated sexually with the moisture contain of 5 to $7 \%$; and kept two seeds in each polythene pouch containing sandy alluvial soil were sown, and saplings were raised up to an age of five weeks. The saplings were transplanted in predesigned experimental plots. Before transplantation the soil of the plots were ploughed and fertilized with a basal dose of cattle dung at the rate of 3.0 tons/hectare and $50 \%$ of required chemical fertilizers (a mix of Urea, Triple Super Phosphate (TSP) and Murat of Potash (MP) at a ratio of $90: 30: 15 \mathrm{~kg}$ per hectare of $\mathrm{N}: \mathrm{P}: \mathrm{K}$, and all other related agronomical practices eg. weeding, irrigation, plat density, harvesting height etc were common.

\section{Experimental layout design}

A uniformly plain land area of $1296.0 \mathrm{~m}^{2}$ was divided into four replications, each of $18 \times 18 \mathrm{sq}$ $\mathrm{m}$ separated by $1.0 \mathrm{~m}$ wide walking alleys. Each plot was planted 1080 sampling at a space of 0.3 $\mathrm{m} \times 0.3 \mathrm{~m}$ per sapling. After 60 days of planting, the Moringa plants were harvested at $40 \mathrm{~cm}$ above the ground level and arranged in a t- test to determine the production response of on station and on-farm condition.

\section{Yield determination and sample collection}

After a post-transplantation growth period of 90 days, top plant parts with leaves (tops) were harvested at a 60 days interval. The plants were allowed to grow after each cut and fertilized after each harvest with $60 \mathrm{~kg}$ Urea N/ha. The biomass yield of each of different cuts of a year was added to determine annual yield of biomass production and a total of six cuts were given. Survival rate (\% of saplings grew after transplantation) and number of prunes per plant were determined. Fresh tops were harvested avoiding any surface water on plants and weighed on a top loading balance and fresh yield per plot was recorded. Fresh yield ( $\mathrm{kg}$ or ton) was converted to DM yield plot $^{-1} \mathrm{ha}^{-1}$ according to the equation: DM yield plot $^{-1}=$ Weight of fresh material $\times$ DM $(\%)$.

\section{Chemical analysis}

The tops were manually separated into stem and leaves to determine stem to leaf ratio and weighed accordingly. Representative samples of tops were taken to determine fresh dry matter, total ash and CP according to AOAC (1990) and acid detergent fiber (ADF) according to Van Soest (1990). All the analyses were done in the animal nutrition laboratory of the BLRI. The tops and stems were chopped manually at a range of 0.03 $\mathrm{m}$ to $0.05 \mathrm{~m}$, dried in the sun and milled for chemical analyses of biomass.

\section{Cost-effectiveness of Moringa fodder with available cash crop}

M. oleifera was cultivated in a thirty two decimal (32) of cultivable land of four farmers at Sadar upazila in Gaibandha district of ABJF-AEZ of Bangladesh. This has resulted in four replications of on farm production of Moringa. The existing cereal crops of the farmers were considered to be control crops, and it was allowed comparison of profitability of Moringa production.

Considering above idea, twenty farmers (20) of the research area were selected on the basis of livestock density and data were collected by direct interviewing from the respondents. A total of 5 cross breed or 5 native dairy cattle having at least two dairy cows were selected under this study. Different necessary information e.g. name of the crops, cropping patterns, yield, total cost of production, harvesting time, market price data were collected for calculating the costeffectiveness of Moringa fodder production at farmers level. 


\section{Feeding experiment of local dairy cows on farm condition}

For determining the $M_{f}$ feeding impact on milk production, twelve local cows of third or fourth parity after 1 to 2 weeks of calving in Gaibandha Sadar Upazila were selected and divided into three dietary groups having four animals in each considering their live weight and ante-diet daily milk yield. During 50 days feeding period all experimental cows were fed freshly threshed rice straw and keeping randomly a group under on farm practice that received supplementation of $\mathrm{CMC}$, the other two groups of cows were either received a commercial cattle feed available at the market or $M_{f}$ replacing the CMC conventional concentrate supplements. The daily energy and $\mathrm{CP}$ requirement of the cows were calculated according to FAO ration tool (2016) and they were met through the diets.

\section{Statistical analysis}

Feeding responses of different diets on different parameters was analyzed in an ANOVA of a Completely Randomized Design (CRD). Collected data of measured parameters were subjected to one way analysis of variance by using SPSS computer programme (2017). Duncan's Multiple Range Test (2011) was applied to separate significant means.

\section{Results}

Production performance and land use efficiency

The production performance and their chemical composition of Moringa fodder at on-station and on-farm condition was shown in Table 1 . The average no. of prunes of Moringa at on-farm condition was significantly $(P<0.05)$ higher $(3.5$ vs 5.07$)$ than that of on-station. It becomes bushier than on-station. The survivability was not significantly $(P>0.05)$ affect by the different climatic zone and it varied from 95.5 to $95.7 \%$.

Table 1: Production performance and quality of Moringa foliage

\begin{tabular}{lcccc}
\hline \multirow{2}{*}{ Parameters } & \multicolumn{2}{c}{ Production Performance } & \multicolumn{2}{c}{ Significance } \\
\cline { 2 - 5 } & On- Station & On-Farm & t-value & Level \\
\hline Survival rate (\%) & $95.5 \pm 2.2$ & $95.7 \pm 1.5$ & -0.10 & $\mathrm{NS}$ \\
No of Prunes/plant & $3.5 \pm 0.13$ & $5.07 \pm 0.2$ & -4.5 & $*$ \\
DM yield; ton/ha/year & $22.7 \pm 1.05$ & $26.6 \pm 0.7$ & -7.7 & $*$ \\
Leaf to stem & $0.45 \pm 0.02$ & $0.45 \pm 0.01$ & -0.72 & $\mathrm{NS}$ \\
\hline Chemical Composition of tops $\left(\mathrm{g} \mathrm{kg}^{-1}\right)$ & & & & \\
\hline DM & $197.0 \pm 1.3$ & $200.1 \pm 1.2$ & -0.17 & $\mathrm{NS}$ \\
Ash & $50.9 \pm 0.4$ & $49.1 \pm 0.6$ & -4.5 & $\mathrm{NS}$ \\
CP & $216.8 \pm 0.1$ & $206.6 \pm 0.4$ & 1.6 & $\mathrm{NS}$ \\
ADF & $331.7 \pm 0.5$ & $315.3 \pm 0.2$ & -3.5 & $*$ \\
\hline
\end{tabular}

Here, non-significant, NS; $*=<0.05$, dry matter, DM; crude protein, CP; acid detergent fiber, ADF;

The annual dry matter (DM) yield of tops at onfarm condition was the height (26.6 ton/ha) compare to on-station (22.7 ton DM/ha/year) and their differences was significant $(P<0.05)$. The leaf to stem ration was similar and did not vary significantly but it reflects that almost a half of the whole tops DM was shared by leaf. The DM, ash and $\mathrm{CP}$ content of tops of Moringa foliage did not differ significantly between the treatments. But the ADF content of Moringa tops was significantly $(P<0.05)$ higher in on-station condition followed by on-farm.
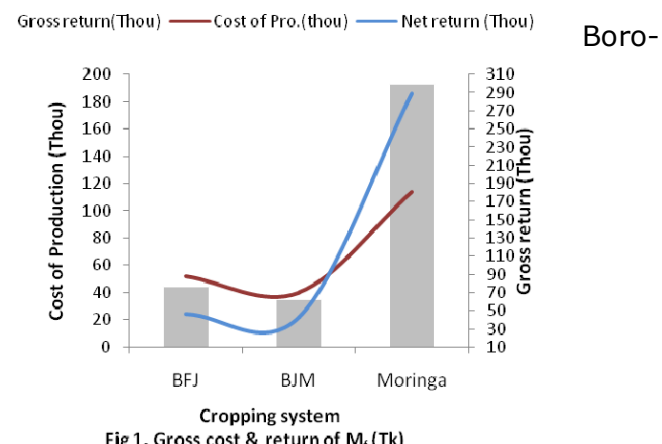

Fig 1. Gross cost \& return of $M_{t}(T k)$

fallow-Jute (BFJ) and Boro-fallow-Muskala (BFM) were the existing cropping system found in the research area under ABJF-AEZ. Figure 1 shows 
that the annual cost of crop production under the two systems was Tk. 51.6 and 40.0 thousand, respectively, while that of $M_{f}$ was Tk. 113.7 thousand. The gross return of the three systems was calculated to be Tk. 76.2, 62.4 and 300.0 thousand, respectively, and gross return was Tk. 24.5, 22.3 and 186.3 thousand, respectively. The highest benefit to cost ratio was found with $M_{f}$ $(2.64: 1)$ followed by BFM $(1.56: 1)$ and BFJ (1.47:1).

\section{Feeding response of Moringa on-farm on local dairy cows}

Total DM (kg/day), ME (MJ/day) and CP (g/day) intake were shown in Table $\mathbf{2}$. The replacement of locally mixed concentrate mixture by $M_{f}$ had a significant effect on daily DM, CP or ME intake. The Moringa group consumed the highest amount of DM, CP and ME $(5.1 \mathrm{~kg}, 543.0 \mathrm{~g}$ and $54.2 \mathrm{MJ}$, respectively) compared to commercial cattle feed $(4.8 \mathrm{~kg}, 273.0 \mathrm{~g}$ and $53.0 \mathrm{MJ}$, respectively) or CMC $(3.8 \mathrm{~kg}, 251.0 \mathrm{~g}$ and $34.6 \mathrm{MJ}$, respectively).

Table 2: Comparative study of $M_{f}$ on nutrient intake of local cows (means \pm SE)

\begin{tabular}{lccccc}
\hline Parameters & \multicolumn{3}{c}{ Experimental rations } & \multicolumn{2}{c}{ Significance } \\
\cline { 2 - 6 } & CMC & $\begin{array}{c}\text { Commercial } \\
\text { cattle feed }\end{array}$ & $\mathbf{M}_{\mathbf{f}}$ & $\begin{array}{c}\text { Overall } \\
\text { SE }\end{array}$ & Level \\
\hline Total DM intake(kg/day) & $3.8^{\mathrm{b}} \pm 0.1$ & $4.8^{\mathrm{a}} \pm 0.1$ & $5.1^{\mathrm{a}} \pm 0.1$ & 0.18 & $P<0.00$ \\
Total ME intake(MJ/day) & $34.6^{\mathrm{b}} \pm 0.9$ & $53.0^{\mathrm{a}} \pm 0.7$ & $54.2^{\mathrm{a}} \pm 0.8$ & 2.7 & $P<0.00$ \\
Total CP intake(g/day) & $251.0^{\mathrm{c}} \pm 7.6$ & $273.0^{\mathrm{b}} \pm 3.2$ & $543.6^{\mathrm{a}} \pm 3.6$ & 37.7 & $P<0.00$ \\
\hline
\end{tabular}

$a, b, c$ means with different superscripts in the same row are significantly different at $(P<0.05)$; conventionally mixed concentrate, $\mathrm{CMC}$; Moringa feed, $\mathrm{M}_{\mathrm{f}}$; dry matter, $\mathrm{DM}$; metabolizable energy, $\mathrm{ME}$; crude protein, $\mathrm{CP}$; standard error of the mean, SE.

The production performances of local dairy cows on $\mathrm{M}_{\mathrm{f}}$ are shown in Table 3. The on-diet (after feeding experimental diets) daily average $4.0 \%$ fat corrected milk production of $M_{f}$ fed cows was the highest $(1.64 \mathrm{~kg} / \mathrm{head})$ followed by 1.10 $\mathrm{Kg} /$ head of market feed and $0.73 \mathrm{Kg} /$ head of cows fed conventionally (Table 3 ). The response difference was significant $(P<0.022)$. The calves of $M_{f}$ suckled significantly $(P<0.01)$ the highest amount of milk $(1.04 \mathrm{~kg} /$ day $)$ than the calves of Market feed $(0.65 \mathrm{Kg} /$ head/day) or CMC $(0.71$ $\mathrm{Kg} /$ head/day) group, and the $M_{\mathrm{f}}$ cows had significantly $(P<0.004)$ highest daily gain $(441.7$ $\mathrm{g} /$ head) compared to the latter $(128.2 \mathrm{~g} /$ head and $48.2 \mathrm{~g} / \mathrm{head}$, respectively).

Table 3: Comparative study of $\mathrm{M}_{\mathrm{f}}$ on milk yield and live weight gain of local cows (means $\pm \mathrm{SE}$ )

\begin{tabular}{|c|c|c|c|c|c|}
\hline \multirow[t]{2}{*}{ Parameters } & \multicolumn{3}{|c|}{ Experimental rations } & \multicolumn{2}{|c|}{ Significance } \\
\hline & CMC & $\begin{array}{l}\text { Commercial } \\
\text { cattle feed }\end{array}$ & $\mathbf{M}_{\mathbf{f}}$ & $\begin{array}{l}\text { Overall } \\
\text { SE }\end{array}$ & Level \\
\hline Ante-diet milk Prod.(kg/day) & $0.83 \pm 0.1$ & $0.81 \pm 0.2$ & $0.96 \pm 0.3$ & 0.1 & $P<0.83$ \\
\hline $\begin{array}{l}\text { On-diet ave. milk prods. } \\
\text { (kg/day) }\end{array}$ & $0.84^{\mathrm{b}} \pm 0.2$ & $1.24^{\mathrm{ab}} \pm 0.1$ & $1.58^{\mathrm{a}} \pm 0.08$ & 0.12 & $P<0.03$ \\
\hline 4\% FCM yield(kg/day) & $0.73^{b} \pm 0.2$ & $1.1^{\mathrm{ab}} \pm 0.2$ & $1.64^{\mathrm{a}} \pm 0.2$ & 0.14 & $P<0.02$ \\
\hline Suckling of milk per day & $0.71^{b} \pm 0.1$ & $0.65^{b} \pm 0.06$ & $1.04^{\mathrm{a}} \pm 0.05$ & 0.06 & $P<0.01$ \\
\hline Fat yield(kg/day) & $0.03^{\mathrm{b}} \pm 0.008$ & $0.04^{\mathrm{ab}} \pm 0.007$ & $0.06^{\mathrm{a}} \pm 0.008$ & 0.006 & $P<0.02$ \\
\hline \multicolumn{6}{|l|}{ Weight gain (g) } \\
\hline Daily weight gain of cows & $48.2^{b} \pm 34.9$ & $128.2^{b} \pm 52.5$ & $441.7^{a} \pm 88.8$ & 60.8 & $P<0.00$ \\
\hline Daily weight gain calves & $349.3 \pm 89.8$ & $448.8 \pm 72.1$ & $529.5 \pm 73.3$ & 46.7 & $P<0.31$ \\
\hline \multicolumn{6}{|c|}{$\begin{array}{l}a, b, c \text { : means with different superscripts in the same row are significantly different at }(P<0.05) \text {; conventionally } \\
\text { mixed concentrate, CMC; Moringa feed, } \mathrm{M}_{\mathrm{f}} \text {; fat corrected milk, FCM; standard error of the mean, SE; FCM = } \\
0.4 \mathrm{M}+15.0 \mathrm{~F} \text {, where } \mathrm{M}=\text { milk yield and } \mathrm{F}=\text { fat yield } \\
\begin{array}{ll}\mathrm{M}_{\mathrm{f}} \text { on milk constituents of local cows are shown in } & \text { the height in } \mathrm{M}_{\mathrm{f}} \text { group }(4.1 \%, 5.9 \% \text { and } 10.8 \\
\text { Table } 4 \text {. The fat percent of local dairy milk did } & \%) \text { and lowest was shown in CMC }(3.7 \%, 5.3 \% \\
\text { not differ significantly but it varied from } 3.2 \text { to } & \text { and } 9.8 \%) \text { and their variation was significant } \\
4.1 \% \text {, respectively. Other constituents like } & (P<0.00) \text { with CMC. }\end{array}\end{array}$} \\
\hline
\end{tabular}




\section{food-feed competitive efficiency of Moringa in Bangladesh}

Table 4: Comparative study of $M_{f}$ on milk composition of local cows (means \pm SE)

\begin{tabular}{lccccc}
\hline $\begin{array}{l}\text { Milk } \\
\text { constituents } \\
(\%)\end{array}$ & CMC & $\begin{array}{c}\text { Commercial cattle } \\
\text { feed }\end{array}$ & \multicolumn{3}{c}{ Significance } \\
\cline { 2 - 6 } & $3.2 \pm 0.02$ & $3.2 \pm 0.49$ & $4.1 \pm 0.4$ & Overall SE & Level \\
\hline Fat & $3.7^{\mathrm{b}} \pm 0.02$ & $3.95^{\mathrm{a}} \pm 0.02$ & $4.1^{\mathrm{a}} \pm 0.1$ & 0.23 & $P<0.15$ \\
Protein & $5.3^{\mathrm{b}} \pm 0.03$ & $5.7^{\mathrm{a}} \pm 0.02$ & $5.9^{\mathrm{a}} \pm 0.2$ & 0.06 & $P<0.00$ \\
Lactose & $9.8^{\mathrm{b}} \pm 0.06$ & $10.6^{\mathrm{a}} \pm 0.06$ & $10.8^{\mathrm{a}} \pm 0.3$ & 0.08 & $P<0.00$ \\
SnF & 9.15 & $P<0.00$ \\
\hline a b and,c,
\end{tabular}

$\mathrm{a}, \mathrm{b}$ and,c: means with different superscripts in the same row are significantly different at $(P<0.05)$; conventionally mixed concentrate, $\mathrm{CMC}$; Moringafeed, $\mathrm{M}_{\mathrm{f}}$; solid not fat, $\mathrm{SnF}$, standard error of the mean, SE.

Figure 2 shows that the feeding of market feed or $\mathrm{M}_{\mathrm{f}}$ increased daily milk yield by $53.09 \%$ and $64.58 \%$, respectively and daily gain by $4.7 \%$ and $13.29 \%$, respectively compared to CMC. It was also shown that $\mathrm{M}_{\mathrm{f}}$ is better than the Market feed in the increase of milk yield and live weight gain of local cows.

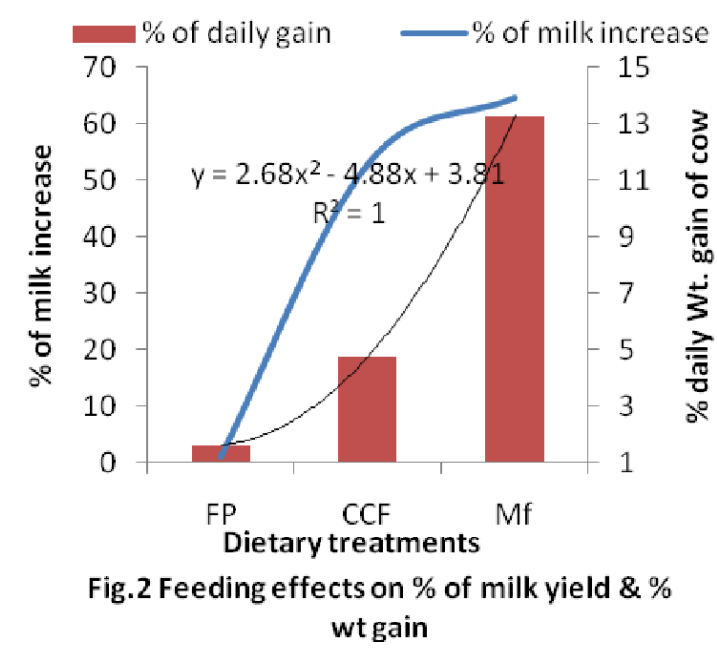

\section{Discussion}

Introducing Moringa at farmer's condition is a new approach for producing good quality animal feed that may avoid food-feed competitions. The motivation for using Moringa fodder is that it has the potential for being an ultimate crop to cereals as well as soybean. The best practices that was produced in on-station condition, it was simply transferred to the on-farm to see what are the actual production performance? Finding shows that pruning ability and annual dry biomass yield of Moringa fodder in on-farm were the height (5.07 and 26.67 ton/hectare). The higher survivability of Moringa foliage and its production performance have been reported by Ezekiel Edward et al. (2014); Benevides (1994); Richter et al. (2003); Sanchez et al. (2006) and
Mendieta-Araica et al. (2011). It may be impacts on wide range soil (Martin, 2007) and may not compete with flood plain arable fertile land used mostly for stable food crop production. The CP contents of Moringa tops reported in this study are within the range of 206 to $216.0 \mathrm{~g} \mathrm{~kg}^{-1} \mathrm{DM}$, reported earlier by Makkar and Becker (1996, 1997); Foidle et al. (1999); Aregheore (2002); Al-Masri (2003); Manh et al. (2003); Sultana et al. (2014) and Minson (1990).

The cost of production of Moringa fodder was the height comparing with available cash crops in the research area. It was TK. 113.7 thousand followed by TK. 51.5 thousand for BFJ and tk. 40.0 thousand for BFM respectively. The Moringa fodder production had the height benefit to cost $(2.64: 1)$ followed by BFM $(1.56: 1)$ and BFJ $(1.47: 1)$. It would be sustainable to the farm level compete with available cash crop. In this context, Adegum and Aye (2013) and Bashar et al. (2016) reported that the cost of production was reduced when the $M$. oleifera leaf meal replaced cotton seed meal and conventional concentrate mixture including $23 \%$ soybean meal in the rations of dairy cows which in turn increase profit and improve the living standard of farmers. The replacement of locally mixed concentrate mixture by the $M_{f}$ the $D M, C P$ and $M E$ intake increased significantly. The present results are in good agreement with those reported by Newton et al., 2010; Mendieta- Araica et al., 2013 and Nouman et al., 2013. They reported that Moringa foliage is rich in most nutrients as its addition to low quality diet is useful to increase their DM intake and nutrient digestibility. The milk production and their growth of local dairy cows increased ( 64.58 and $13.29 \%$ ) significantly by the replacement of $M_{f}$. Similar assumption was reported by Sarwatt et al., 2004 who stated that the small amount of Moringa leaves meal improved the rumen environment which was implied on better feed utilization and milk production. Rayes Sanchez et al. (2006b) also 
found that daily milk production was significantly higher for dairy cows fed $M$. oleifera supplement than those fed B. brizan hay only. They added that the improvement of milk production was associated with an increased of fat and protein yield.

\section{Conclusion}

Considering the above discussion it is ravel that feeding of $M_{f}$ increased milk yield and live weight gain of cows compared to Market feed or CMC. In addition to increased gross return per hectare of crop land from $M_{f}$ production, a higher efficiency conversion of $M_{f}$ biomass into human edible protein through increased milk yield and live weight gain of cows and calves and probable reduction of enteric $\mathrm{CH}_{4}$ emission in local cows will further substantiate on farm $M_{f}$ production avoiding food-feed competitions for land sustainably.

\section{Acknowledgment}

This study was sponsored by the Department of Livestock Services, Ministry of Fisheries and Livestock, The Government of the People's Republic of Bangladesh. The authors would like to be grateful to Fodder Research and Development Project, Bangladesh Livestock Research Institute, Savar, Dhaka

\section{References}

Sultana N, Huque KS, Alimonand AR and Hossain SMJ (2012). Study on Moringa oleifera foliage as a feed for growing male goats; In the proceedings of the Annual Research review workshop, Bangladesh Livestock research Institute, Savar, Dhaka, Bangladesh.

Huque KS, Bashar MK, Sarker NR, Sultana N and Makkar HPS (2017). Biomass production, chemical composition and In-sacco degradability of different cultivars of Moringa oleifera. International Journal of Environment, Agriculture and Biotechnology (IJEAB) Vol-2(2): 864-873.

AOAC. 1990. Official Methods of Analysis. 15th edn. Association of Official Analytical Chemists, Arlington, VA, USA: 1-1298.

Van Soest, PJ (1990). Fibre utilization. Proc. 26th Nutr. Conf. Feed Manuf. Dep. Anim. Sci., Feed Ind. Assoc., Univ. Guelph, Can: 110.

Ezekiel Edward AO, Shabani Chamshama M, Yonika Ngaga and Mathew A. Mndolwa (2014). Survival growth and biomass production of Moringa oleifera provenances at Gairo inland plateau and Ruvu Coastal Region in Tanzania. African Journal of Plant Science Vol. 8(1): 5464.

Benavides JE (1994). La Investigacio'n en a' rboles Forrajeros. In: a' rboles y Arbustos Forrajeros en Ame'rica Central. CATIE, Turrialba, CR, 1, 3-28.
Richter NS, Perumal and Klaus B (2003). Evaluation of nutritional quality of Moringa (Moringa oleifera Lam.) leaves as an alternative protein source for Nile tilapia (Oreochro misniloticus L.). Aquacul 217: 599-611.

Sanchez NR \& Inger L (2006). Biomass production and chemical composition of Moringa oleifera under different management regimes in Nicaragua. Agrofores Sys 66: 231-242.

Mendieta-Araica B, Spomdly R, Sanchez NR and Spomdly E (2011). Moringa (Moringa oleifera) leaf meal as a source of protein in locally produced concentrates for dairy cows fed low protein diets in tropical areas. Livestock Sci.137: 10-17.

Makkar HPS and Becker K (1996). Nutritional value and anti nutritional components of whole and ethanol extracted Moringa oleifera leaves. Anim Feed SciTech nol 63: 211-228.

Makkar HPS and Becker K (1997). Nutrients and antiquality factors in different morphological parts of the Moringa oleifera tree. J Agric Sci Camb128: 311-332.

Aregheore EM (2002). Intake and digestibility of Moringao leifera-batiki grass mixtures by growing goats. Small Rumin Res 46: 23-28.

Manh LH, Dung NNX and Xuan VT (2003). Biomass production of Moringa oleifera and some legumes in the hilly area of Tinh Bien district, An Giang province. In proceedings workshop for sustainable livestock production on local feed resources. SAREC-UAF, Hue, Vietnam: 25-27.

Al-mashri MR (2003). An in vitro nutritive evaluation and rumen fermentation kinetics of Sesbania aculeataas affected by harvest time and cutting regimen. Trop. Anim. Health Prod. 41: 11151126.

Minson DJ (1990). Forage in Ruminant Nutrition. Academic Press, San Diego, CA, $482 \mathrm{p}$.

Adegun, M. K. and Aye, P. A. (2013). Growth performance and economic analysis of West African dwarf rams fed Moringa oleifera and cotton seed cake as protein supplements to Panicum maximum. Am. J. Food. Nutr, 3(2): 58-63.

Bashar MK, Huque KS, Sarker NR, Sultana N and Makkar HPS (2016). Study of Moringafeed $\left(M_{f}\right)$ impacts on daily milk production and their quality. Proceeding of BLRI.

Newton KA, Bennett RN, Curto RB, Rosa EA, Turc VL, Guiffrida A, Curto AL, Crea F and Timpo GM (2010). Profiling selected phytochemicals and nutrients in different tissues of the multipurpose tree Moringa oleifera L.,grown in Ghana.Food Chem. 122:1047-1064.

Nouman W, Basra S, Yasmeen MT, Gull A and Alcayde MA (2013). Potential of Moringa oleifera L. as livestock fodder crop: a review. Turk. J. Agric., doi. 10.3906/tar: 1211-66.

Reyes- Sanchez N, Sporndly E and Ledin I (2006b). Effect of feeding different levels of 21 foliage of Moringa oleifera to creole dairy cows on intake, digestibility, milk production and composition. Livestock Science 1001: 21-31. 